\title{
Analyzing Primary Social Studies Curriculum of Turkey in Terms of UNESCO Educational for Sustainable Development Theme
}

\author{
Elvan YALÇINKAYA ${ }^{1}$
}

\begin{abstract}
:
These three terms have been used at website of UNESCO: Sustainable development (SD), education for sustainable development (ESD) and the United Nations Decade of Education for Sustainable Development (DESD). In this website, it is mentioned that the three terms have the same goal; creating a better world for this generation and future generations of all living things on planet Earth. The aim of this study is to analyze Primary Social Studies Curriculum of Turkey in terms of UNESCO ESD Theme. Data was obtained from Social Studies Curriculum. In this study, Social Studies Curriculum of Turkey was discussed in terms of three perspectives which are stated in UNESCO's Framework for the United Nations Decade of Education for Sustainable Development International Implementation Scheme (DESD). These three perspectives are; sociocultural, environmental and economic perspectives. As a result, in this study, it is concluded that Social Studies Curriculum should be improved in terms of ESD. It is suggested that authorities, academics, program developers, teachers should consider the multidisciplinary feature of both Social Studies Curriculum, and education for sustainable development.
\end{abstract}

Keywords: Sustainable development, Education for sustainable development, Social studies education, Turkish social studies curriculum.

\section{Introduction: Educational For Sustainable Development}

According to UNESCO's latest documents, sustainable development is the "ultimate goal of the human-environment relationships"; so, the whole educational process should be "reshaped for sustainable development." In view of the extreme importance of their educational impact, such statements need to be discussed (Sauve, 1996: 7). There is lack of education on the basis of issues obstacle the sustainability (Karatas, 2011). ESD is fundamentally about values and respect for future and past generations, for difference and diversity, for the environment, and for natural resources (Scoullos, 2010: 54). ESD's primary

${ }^{1}$ Niğde University, Faculty of Education, Department of Primary Education, Turkey, 
concern is the improvement of the quality of life for people without damaging the environment (Nevin, 2008: 56). According to Özdemir (2007: 25) it is fundamental to establish a new perception aiming to fortify sustainable living culture on the earth and focusing on the development of cognition, affection, skills and abilities in compliance with this perception.

These three terms have been used at website of UNESCO: Sustainable development (SD), education for sustainable development (ESD) and the United Nations Decade of Education for Sustainable Development (DESD). In this website, it is mentioned that the three terms have the same goal; creating a better world for this generation and future generations of all living things on planet Earth. According to UNESCO sustainable development (SD) is a complex undertaking, with connections to every part of life. In planning and implementing the ESD it is important to maintain these connections so that the learning process gives people the chance to apply sustainable development principles across their lives, and to understand the multiple impacts of their actions and behaviour. Also, for UNESCO, ESD allows every human being to acquire the knowledge, skills, attitudes and values necessary to shape a sustainable future. In the Scheme of Framework for the United Nations Decade of Education for Sustainable Development (DESD) International Implementation (2006), it is pointed out that ESD is fundamentally about values, with respect at the centre; respect for others, including those of present and future generations, for difference and diversity, for the environment, for the resources of the planet we inhabit. This plan presents three key areas of sustainable development; society, environment and economy with culture as an underlying dimension. Sustainable development is usually presented as the intersection between environment, society and economy, which are conceived of as separate although connected entities (Giddings, Hopwood \& O'Brien, 2002; Holmberg ve Sandbrook, 1992; Sauve, 1996; UNESCO, 2006; Nevin, 2008).

These three elements, reaffirmed at the Johannesburg Summit as the 3 pillars of sustainable development, give shape and content to sustainable learning (UNESCO, 2006):

Society: an understanding of social institutions and their role in change and development, as well as the democratic and participatory systems which give opportunity for the expression of opinion, the selection of governments, the forging of consensus and the resolution of differences.

Environment: an awareness of the resources and fragility of the physical environment and the affects on it of human activity and decisions, with a commitment to factoring environmental concerns into social and economic policy development.

Economy: a sensitivity to the limits and potential of economic growth and their impact on society and on the environment, with a commitment to assess 
personal and societal levels of consumption out of concern for the environment and for social justice.

"There are two commonly used visualisations of how the various aspects of sustainable development interact: one is of three overlapping circles representing the three pillars of sustainable development - economy, society and environment (Figure 1). The other shows the economy embedded in society, which in turn is embedded in the environment (Figure 2). The latter focuses on the central role that the environment plays in human society and in turn in the economy" (Nevin, 2008: 49).

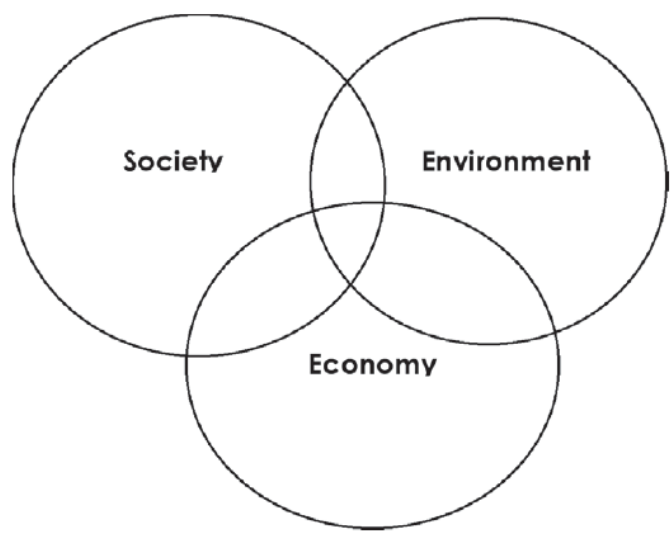

Figure 1. Overlapping pillars of sustainable development

Resource: Nevin, 2008:50

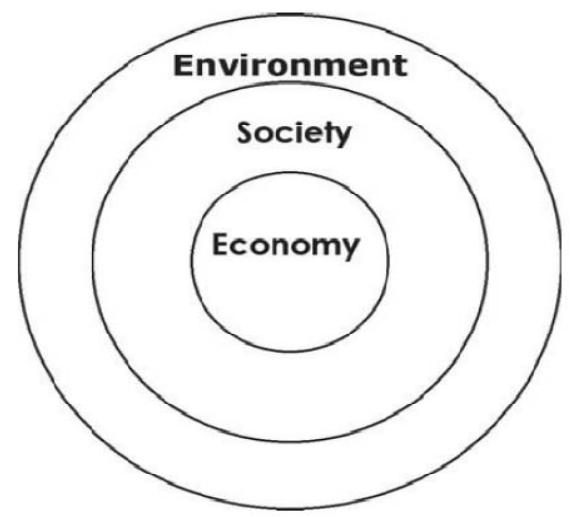

Figure 2. Concentric circles visualization of sustainable development

Resource: Nevin, 2008: 50

It has been declared as the Education Decade of United Nations for Sustainable Development between the years 2005-2014. The main aim is to create learning opportunities enabling to form new lifestyles, values and attitudes for an 
economical, social as well as environmental sustainable future (Demirbaş, 2011: 596). Educating for a Sustainable Future, a program prepared by UNESCO, postulates that economic development is at the basis of human development and recognizes that a sustainable economy is closely linked to the conservation of natural resources and the equitable sharing of resources (Tanriverdi, 2009: 90). In 2005, member States adopted the United Nations Economic Commission for Europe (UNECE) Strategy on ESD in order to promote ESD in the region. The Strategy is a practical instrument to incorporate key themes of sustainable development into the region's education systems. These themes include a wide range of issues: poverty alleviation, peace, ethics, democracy, justice, security, human rights, health, social equity, cultural diversity, economy, environmental protection, natural resource management. The aim of this Strategy is to encourage countries to develop and incorporate ESD into their formal education systems, in all relevant subjects, and in non-formal and informal education.

The objectives of this Strategy, which will contribute to the achievement of the aim, are to:

- $\quad$ Ensure that policy, regulatory and operational frameworks support ESD;

- $\quad$ Promote SD through formal, non-formal and informal learning;

- $\quad$ Equip educators with the competence to include SD in their teaching;

- $\quad$ Ensure that adequate tools and materials for ESD are accessible;

- $\quad$ Promote research on and development of ESD;

- Strengthen cooperation on ESD at all levels within the UNECE region.

In order to be effective, ESD should enable (UNECE, 2005 cited in Scoullos, 2010: 57):

Integration of ESD themes across all relevant subjects, programmes, and courses; the provision of specific subject programmes and courses.

- Meaningful learning experiences that foster "sustainable behavior".

- Learning activities in close relation with society adding to learners' practical experience.

An insight into global, regional, national, and local environmental problems; explaining them by means of a life-cycle approach and focusing not only on the environmental impact, but also on the economic and social implications, addressing both the natural environment and that modified by humans.

A wide range of participatory, student-centred and solution oriented educational methods, including discussions, conceptual and perceptual mapping, philosophical inquiry, value clarification, simulations, scenarios, modelling, role playing, information and communication technology, surveys, case studies, 
learnerdriven projects, good practice analyses, workplace experience, and problem solving.

- $\quad$ All pupils and students should acquire appropriate knowledge of SD and become aware of the impact of decisions that do not support SD.

- Appropriate training and re-training of educators.

- Support of the non-formal and informal ESD activities, as essential complements to formal education.

ESD mirrors the concern for education of high quality, demonstrating characteristics: such as (UNESCO, 2006):

Interdisciplinary and holistic: learning for sustainable development embedded in the whole curriculum, not as a separate subject;

Values-driven: sharing the values and principles underpinning sustainable development;

Critical thinking and problem solving: leading to confidence in addressing the dilemma and challenges of sustainable development;

Multi-method: word, art, drama, debate, experience,... different pedagogies for modelling processes;

Participatory decision-making: learners participate in decisions on how they are to learn;

Applicability: learning experiences are integrated in day to day personal and professional life;

Locally relevant: addressing local as well as global issues, and using the language(s) which learners most commonly use.

The aim of this study is to analyze Primary Social Studies Curriculum of Turkey in terms of UNESCO ESD Theme. Data was obtained from Social Studies Curriculum. Schools split up into 3 grades (primary school, secondary school and high school) in new Turkish system of education in which compulsory education is 12 years $(4+4+4)$. This research has been delimitated with primary school social studies lesson. Because of the fact that social studies lesson is only taught at $4^{\text {th }}$ grade of primary school, only curriculum of $4^{\text {th }}$ grade has been examined in this study. In this study, Social Studies Curriculum of Turkey was discussed in terms of three perspectives which are stated in UNESCO's plan (DESD). These three perspectives are; socio-cultural (human rights, peace and human security, gender equality, cultural diversity and intercultural understanding, Health, HIV/AIDS, governance), environmental (natural resources, climate change, rural development, sustainable urbanisation, disaster prevention and mitigation) and economic perspectives (poverty reduction, corporate responsibility and accountability, market economy). 


\section{General overview to Turkish social studies curriculum in terms of ESD (education for sustainable development)}

Social studies education in Turkey is an interdisciplinary field. In Turkish Social Studies Curriculum Social Studies course is defined as a primary education course reflecting history, geography, economy, sociology, anthropology, psychology, philosophy, political sciences, law and nationality subjects; consisting of combining learning domains in a unit or theme; in which the interaction between social and physical environment of a person is examined in terms of past, present and future; and that is formed based on mass teaching understanding by Ministry of National Education (MEB) (2005). The content of primary social studies course of $4^{\text {th }}-7^{\text {th }}$ grades is based on the disciplines take part in social sciences field.

Social studies course is accepted as application area of civics and democracy (Sahiner, 2008:3). Social studies lesson, which can be seen as the application area of citizenship and democracy education, have a bearing on history, geography and civics through long years. However, in the social studies curriculum of 2005 that has been prepared according to constructivist approach the effect of history, geography and civics has been decreased; the effect of sociology, anthropology, political sciences, economy etc. has been increased. This characteristic of social studies lesson in Turkey is very important in terms of ESD. That is because; social studies lesson can take on a task in teaching socio-cultural, economic and environmental sides of ESD to children beginning from little ages.

The basics forming Social Studies Curriculum: skills, concepts, values and general purposes (MEB, 2005). The skills to be acquired by the students in the curriculum include the followings:
- $\quad$ Critical Thinking
- Creative Thinking
- Communication
- Research
- $\quad$ Problem Solving
- Making Decision
- Using Information Techniques
- $\quad$ Entrepreneurship
- Using Turkish in a Good and Effective Way
- Observation
- Environment Sense
- $\quad$ Time and Chronology Sense
- $\quad$ Change and Invariability Sense 
- $\quad$ Social Participation

- $\quad$ Empathy

According to Kaya andTomal (2011), the above mentioned entire 15 items are for sustainable development education, but "Change and Invariability Sense" skill is directly and other skills are indirectly about sustainable development education. In fact it isn't totally true to say that the skills mentioned in curriculum are directly about ESD. These skills, which are aimed to be taught to the student in social studies lesson, can be evaluated as basic skills in a sustainable development. Today's people should be equipped with these skills in terms of taking prospectively decisions, actualizing these decisions and contributing humankind. Offering some opportunities to individuals from very young ages in order to make them approach social, economic, cultural and political events and concepts with critical and creative view is among the aims of ESD.

It can be seen that the concepts those take place in Social Studies Curriculum are mostly about ESD. For example; the concepts that should be brought students in $4^{\text {th }}$ grade such as "catastrophe, environment, environmental pollution, distribution, solidarity, invariability and change, natural environment, economy, economical activities, labor, energy, income and expense, waste, attendance, source, money, market, responsibility, rights and freedoms, consumption, production, management, citizenship" are about ESD.

Also, values in the curriculum are as follows:

$\begin{array}{ll}\text { - } & \text { Justice } \\ \text { - } & \text { Giving importance to family unity } \\ \text { - } & \text { Pndependence } \\ \text { - } & \text { Scientific } \\ \text { - } & \text { Diligence } \\ \text { - } & \text { Solidarity } \\ \text { - } & \text { Sensitivity } \\ \text { - } & \text { Honesty } \\ \text { - } & \text { Aesthetic } \\ \text { - } & \text { Tolerance } \\ \text { - } & \text { Hospitality } \\ \text { - } & \text { Freedom } \\ \text { - } & \text { Giving importance to be healthy } \\ \text { - } & \text { Respect } \\ \text { - } & \text { Love } \\ \text { - } & \text { Responsibility } \\ \text { - } & \text { Cleaning }\end{array}$


- Patriotism

- Charity

The values those take place in Curriculum is very important in terms of ESD. According to Kaya and Tomal (2011), it is possible to say that an individual should have these values in terms of knowing, protecting social values and handing them down to next generations.

$4^{\text {th }}$ grade Social Studies Curriculum consists of "Individual and Society", "Culture and Heritage", "People, Places and Environments", "Production, Distribution and Consumption", "Science, Technology and Society", "Groups, Corporations and Social Organizations", "Power, Management and Society", "Global Connections" and "Time, Invariability and Change" learning domains. In the program the acquirements take place in different titled units according to every learning domain. Below the ratios and numbers of total acquirements in every learning domain and the acquirements intended sustainable development education are shown in a table. As it can be understood from the table, one can see that $47.8 \%$ of the acquirements those take place in the curriculum are about ESD.

Table 1. The distribution of gains related to ESD in social studies curriculum

\begin{tabular}{lccc}
\hline Learning Domain & $\begin{array}{c}\text { Total } \\
\text { Acquisition } \\
\text { Number (f) }\end{array}$ & $\begin{array}{c}\text { Acquisition } \\
\text { Number For } \\
\text { ESD (f) }\end{array}$ & $\begin{array}{c}\text { The Ratio of } \\
\text { the Acquisition } \\
\text { for ESD (\%) }\end{array}$ \\
\hline $\begin{array}{l}\text { Individual and Society } \\
\text { Culture and Heritage }\end{array}$ & 6 & 1 & 16.7 \\
$\begin{array}{l}\text { People, Places and Environments } \\
\text { Production, }\end{array}$ & 6 & - & - \\
$\begin{array}{l}\text { Consumption } \\
\text { Science, Technology and Society }\end{array}$ & 8 & 4 & 50 \\
$\begin{array}{l}\text { Groups, Corporations and } \\
\text { Organizations }\end{array}$ & 7 & 6 & 85.7 \\
$\begin{array}{l}\text { Power, Management and Society } \\
\text { Global Connections }\end{array}$ & 5 & 3 & 33.3 \\
Total & 4 & 2 & 60 \\
\hline
\end{tabular}

\section{Turkish primary school social studies curriculum in terms of ESD perspectives of UNESCO}

UNESCO (2006) has determined fifteen strategic perspectives for ESD. Many of these perspectives are identified in Agenda 21 and/or the Johannesburg 
Plan of Implementation as important concerns and challenges that must be addressed in the effort to achieve sustainability. They will also serve to identify stakeholders and partners in the implementation of the Decade (UNESCO, 2006).

\subsection{Socio-cultural perspectives}

Human rights: When we look at the program in terms of human rights, we can see that especially the acquisitions those take place in "Individual and Society" learning domain are about human rights. For example, it can be seen that "respect to feelings and thoughts, toleration" value is aimed to be taught with the acquisition of "an individual respects others feelings and thoughts". Besides that it can also be seen that these perspective of ESD is about "Human Rights and Citizenship" sub discipline of the program.

Peace and buman security: There isn't a direct discipline in primary school Social Studies Curriculum about peace and human security. However "peace" is among the humanitarian values those have to be brought in. from this aspect it can be said that peace and human security subject is tried to be taught implicitly.

Gender equality: There isn't any acquisition about gender equality in the program. But gender equality takes place in the basic principles of Turkish National Education and the purposes of the Social Studies Curriculum Program.

Cultural diversity and intercultural understanding: It can be seen that the acquisitions in "My Friends who are Far Away" unit of "Global Connections" learning domain are directly about cultural diversity and intercultural understanding. In the program it is expressed that students will acquire the qualification of an individual who be up to date of developing world, solve the problems they come across and responsible with "Global Connections" learning domain.

Health: In the program there isn't any acquisition about health subject. However "cleanliness and caring about being healthy" take place among the values those have to be taught to the students directly. Besides that "Health Culture" sub discipline is directly about ESD.

HIV/AIDS: It can be seen that there is not any information about HIV/AIDS in the program. Information about this subject takes place in Science and Technology lessons in Turkey. In terms of putting interdisciplinary and holistic characteristics of ESD, some acquisitions about this subject can be included in Social Studies Curriculum.

Governance: "All Together" unit of "Groups, Corporations and Social Organizations" learning domain is totally about governance. In the program it is expressed that it is important for students to know how groups, corporations and social organizations are formed; the mechanisms effecting and controlling them; how they effect and control individuals and how they continue their existence and change. 


\subsection{Environmental perspectives}

Natural resources (water, energy, agriculture, biodiversity): It can be seen that especially geography subjects of social studies lesson are about this perspective. We can clearly understand this situation form the explanations about learning domain taken from the program (MEB, 2005):

With "People, Places and Environments" learning domains it is aimed to teach to the students to know interaction of people with their environment, understand the causes and effects of this interaction by using some skills and values or gain social point of view.

People, place and environment interaction forms a wide range. Thanks to today's technological developments people can communicate with the world, by this means they are being affected and they effect. The desire to be modern and reflect being modern to education life requires students to comprehend these interactions processes. This deficiency will tried to be made up with "People, Places and Environments" learning domain.

Disaster prevention and mitigation: About this direct perspective, "an individual is ready for catastrophes" acquisition takes place in $4^{\text {th }}$ grade "The Place We Live" unit. Also with the sub disciplinary of "Preventing from Disasters and Safe Life" it is aimed to make students ready for natural disasters. The activities named "earthquake exercise, preparing class release bag" are about ESD perspective.

In $4^{\text {th }}$ grade program there is not any acquisition about "climate change, rural development, sustainable urbanization" perspectives.

\subsection{Economic perspectives}

According to UNESCO economic perspective consists of three sub perspectives such as poverty reduction, corporate responsibility and accountability, market economy. When we look at Social Studies Curriculum in terms of economic perspective, we can see that economy, which became one of the important fields of social studies, makes its effect felt in the program. Especially "Production, distribution and consumption" learning domain has been formed with economy based approach. This learning domain focuses on bringing in entrepreneurship value. We can understand how this learning domain corresponds with ESD's purposes from the explanations those take place in the program (MEB, 2005):

"In this learning domain $4^{\text {th }}$ and $5^{\text {th }}$ grade students recognize their desires and needs and their differences. They recognize the fact that their desires are unlimited but the sources are limited. They learn to form their desires in appropriate for the available sources and the foundation of being a conscious consumer has been laid. He understands the fact that the sources of the country are also limited and understands the importance of protecting the available sources. He compares his own economic life with the others', presents the differences and the similarities. He examines the economic conditions of where he lives and tries to develop them. "Production, Distribution and Consumption" is the typical theme of related units and subjects. Students learn basic concepts about production, distribution and consumption. They know that professions exist to make our lives easier." 


\section{Results and Suggestions}

The conclusion is that Primary School Social Studies Curriculum in Turkey is about ESD, but it is not enough. Same results have been found by Kaya and Tomal (2011). Also it has been presented with the studies of Yapici (2003), Alim (2006), Tanriverdi (2009) and Ozturk Demirbas (2011) that curriculums in Turkey aren't enough in terms of sustainable debelopment.

The researcher has precipitated that some domains such as gender equality, HIV/AIDS, climate change, rural development, sustainable urbanization those are very important for ESD recently don't take place in the program. On the other hand, it is thought that the environmental aspect of ESD is inadequate in the program. Only a few findings about natural sources and disaster awareness have been found in the program about environmental aspect of ESD. It draws attention that other aspects of environment aren't considered much.

As a result, in this study, it is concluded that Social Studies Curriculum should be improved in terms of ESD. It is suggested that authorities, academics, program developers, teachers should consider the multidisciplinary feature of both Social Studies Curriculum, and education for sustainable development.

\section{References}

Alım, M. (2006). Avrupa Birliği üyelik sürecinde Türkiye'de çevre ve ilköğretimde çevre eğitimi. Kastamonu Ë̆itim Dergisi, 14(2), 599-616.

Demirbaş, Ö. Ç. (2011). Coğrafya dersi öğretim programında sürdürülebilir kalkınma. Uluslar arasi Insan Bilimleri Dergisi, 8(2), 596-615. [Online]: http://www.insanbilimleri.com

Giddings, B., Hopwood, B. \& O’Brien, G. (2002). Environment, economy and society: Fitting them together into sustainable development. Sustainable Development, 10, 187-196.

Holmberg, J. ve Sandbrook, R. (1992). Sustainable Development: What Is to Be Done? Making Development Sustainable: Redefining Institutions, Policy, and Economics. (Ed. J. Holmberg). International Institute for Environment and Development, p. 19-38, Island Press, Washington, D. C.

Karataş, A. (2011). Role of natural of history museums for increasing environmental awareness. Journal of Akademik Bakıs, 27, 1-15. [Online]:

http://akademikbakis.org/27/11.pdf

Nevin, E. (2008). Education and sustainable development. Policy \& Practice: Education for Sustainable Development, 6, 49-62. [Online]: http://www.developmenteducationreview.com/issue6-focus4

Scoullos, M. J. (2010). Education for sustainable development: The concept and its connection to tolerance and democracy. In A. Nikolopoulou, T. Abraham \& F. 
Mirbagheri (Eds.), Education for sustainable development. pp. 47-63. New Delhi, India: Sage.

Şahiner, D, G, S. (2008). İlkögretim sosyal bilgiler dersinde aktif ögrenme tekniklerinin demokratik tutumlara ve ders basarısina etkisi, Dokuz Eylül Üniversitesi Eğitim Bilimleri Enstitüsü Yayımlanmamış Yüksek Lisans Tezi. İzmir.

Özdemir, O. (2007). Yeni bir çevre eğitimi perspektifi sürüdürülebilir gelişme amaçlı eğitim. Ë̆itim ve Bilim, 32(145), 23-39.

Öztürk Demirbaş, Ç. (2011). Coğrafya dersi öğretim programında sürdürülebilir kalkınma. Uluslararası Insan Bilimleri Dergisi, 8(2), 595-615. [Online]: http://www.insanbilimleri.com

Sauve, L. (1996). Environmental education and sustainable development: A further appraisal. Canadian Journal of Environmental Education, 1, 7-34.

Tanrıverdi, B. (2009). Sürdürülebilir çevre eğitimi açısından ilköğretim programlarının değerlendirilmesi. Ĕ̈itim ve Bilim, 151, 89-103.

Turkish National Education Ministry (MEB). (2005). Sosyal Bilgiler Öğretim Program. [Online]: http://ttkb.meb.gov.tr/

UNECE. (United Nations Economic Commission for Europe). 2005. Strategy for education for sustainable development. Adopted at the Highlevel meeting of Ministers of Environment and Education of UNECE Member States, Vilnius (Lithuania), March 17. [Online]: www.unece.org.

UNESCO, (2006). Framework for the UN DESD International Implementation Scheme.

Yapıc1, M. (2003). Sürdürülebilir kalkınma ve eğitim. AKÜ Sosyal Bilimler Dergisi, 5 (1), 223230. 